strated by the Museum staff. Afterwards a visit was paid to the offices of the Scottish branch of H.M. Geological Survey. Here all branches of the work were illustrated by carefully prepared exhibits including photographs, maps, rock collections and models. On Monday evening the fellows of the Society and the delegates were received by the Lord Provost and Town Council of the city. Tuesday's programme opened in the Geology Department of the University with a welcome by the principal, Sir Thomas Holland, who gave an address on the position of geology at the time the Society was founded. This was followed by addresses by Prof. F. D. Adams of Montreal, who dealt with the beginnings of Canadian geological survey. Prof, C. F. Kolderup, of Bergen, compared the geology of Norway with that of Scotland, and Prof. Baron de Geer gave an interesting summary of the work on varve-clays and their possible use in correlating glacial deposits throughout the world. Prof. W. N. Benson, of New Zealand, described the work of Sir James Hector, who was a graduate of the University of Edinburgh and a member of the Society and initiated the geological survey of New Zealand. The aftemoon was devoted to a tour of places of geological interest within the city. The celebrations were brought to a close on Tuesday evening when the Society entertained its delegates to a dinner.

\section{International Scientific Radio Union}

A PLENARY congress of the International Scientific Radio Union (Union Radio Scientifique Internationale) is being held in London on September 11-19. The "U.R.S.I." is one of the constituent bodies of the International Council of Scientific Unions, and its secretariat is conducted by Dr. R. B. Goldschmidt in Brussels. This is the first occasion on which the Union has met in London, and representatives of some twelve or more nations are in attendance. The Congress is being held in the rooms of the Royal Society, Burlington House, with Dr. W. H. Eccles acting for the president of the Union, Prof. A. E. Kennelly, who is unfortunately prevented by ill-health from making the journey from the United States. The British National Committee of the U.R.S.I. is led by its president, Prof. E. V. Appleton, with Prof. S. Chapman as secretary and Dr. E. H. Rayner as president of the reception committee. The work of the assembly is divided among five commissions dealing respectively with radio measurements and standards, the propagation of waves, atmospherics, liaison, and radio physics. Subcommissions have been appointed to deal with the detail work on the agenda falling under these subjects. The Lundon meeting includes certain technical visits and other appropriate engagements of interest to the delegates from other countries.

\section{Prehistoric Shetland}

A Remarkable view of the life and culture of settlements of prehistoric and Viking times is given in the results of excavations, which have now been carried on for four seasons, at a promontory in the inlet of Sumburgh Voe at the southern extremity of the Shetlands, by Mr. A. O. Curle under the Office of Works. The site was first brought to light about thirty years ago, when, as the result of a storm, a brock and subsidiary buildings, of which the occupation probably extended into the Christian era, were found on the foreshore. According to an account of the present season's excavations in the Times of September 10, several dwelling-places have been explored, some belonging to the prehistoric settlement, others to the Viking settlement, which is dated at the tenth to twelfth centuries. The prehistoric inhabitants were a simple pastoral people, of stone age culture, whose pottery suggests the Iron, rather than the Bronze, Age. In the oldest of the dwellings as yet examined, there are three phases of occupation and, in the third of these, moulds for bronze weapons and implements appear. In the later occupation of the site, bronze gives way to iron, while the earlier simple unornamented pottery with a plain rounded rim is replaced by pots with the deep hollowed rim characteristic of the Continental Hallstat culture. Towards the close of the Bronze Age, souterrains were in use, of which three have been found. Cattle were housed in the dwellingplace, and the people lived in small lateral chambers. In front of one of these was a quern, while four steatite vessels stood on a bench in front of another. One Viking house, which has been excavated, gives a remarkably complete view of the internal arrangements and method of roofing of the structure. Among numerous Viking relics the most noteworthy is a series of engraved slates, on one of which is a sketch of a Viking galley, singularly detailed within the limitations of the technique.

\section{Anthropology and the African}

THE presidential address to the Royal Anthropo. logical Institute delivered by the Rev. E. W. Smith (J.R. Anthrop. Inst, , 64, Pt. 1) is noteworthy as a carefully balanced survey of the arguments which have been advanced for and against anthropological studies as a factor in the future development of the African, by one who has had a prolonged experience of the practical problems which arise in close intercourse with the less-advanced peoples of the continent. While pointing to the advances which have been made in the practical application of anthropological principles and knowledge of anthropological data in the problems of administration, he also stressed the fact that the 'open door' is by no means entirely won. In dealing with criticism of missionaries and the criticism of anthropologists by missionaries, his views as a member of both bodies should do much to remove a general misapprehension as to the relation of the two systems, which, as he showed, are by no means incompatible in praotice. For while he admitted that in earlier days missionaries had tended to introduce into missionary teaching much which belonged to Western civilisation rather than to Christianity, a new body of missionaries is growing up whose work is carried on in a spirit analogous to that of the administration under 'indirect rule' by the effort to build on African institutions and sentiment, preserving what is good 
in it, rather than destroying it entirely, as too often was the endeavour of earlier generations. It has been noted recently that a feeling of disillusion and pessimism is appearing among Africans; but $\mathrm{Mr}$. Smith looks to win the co-operation of the African in his own development, and in this connexion regards hopefully the interest he is beginning to take in the systematic study of his culture and institutions.

\section{Training for Management}

DURING recent years, considerable interest has developed in the possibilities of specialised training for business management. Such training, it is recognised, is not a substitute for experience but a supplement, or rather a preparatory basis, which provides a broader foundation on which experience can build. The applications of science to industry, intensified world competition, the increasing complexity of industrial organisation and other factors have combined to make the task of successful management far more complicated and difficult than it was in the past. To provide for the systematic training of men for responsible posts in business, a Department of Business Administration was established at the London School of Economics in 1930 through the joint efforts of leading business firms and the authorities of the School. Selected students are given fulltime training in the broad principles of business administration, and throughout the course efforts are made to keep the teaching in close touch with reality through discussions opened by business men and by visits to factories, shops and offices. Special attention is paid to marketing, retail management and sales management, and instruction in these subjects is based on fresh investigations into current practice. The recently issued prospectus of the Department for the coming session shows that during the past three years nearly fifty students have passed through it, most of them university graduates. Last summer, the Department began an experiment in training which was designed to be of practical help in bridging the gap between university study and entry into business. Under this scheme, which is being extended during the coming session, a number of firms offer appointments to university graduates of high standing who are selected by them and approved by the Department on condition that they attend the specialised business course during the academic year from October until June.

A management course for industry and commerce, which covers departmental functions, methods, problems, underlying sciences and managerial mental activity is being given by Mr. W. R. Dunlop, 57 Gordon Square, London, W.C.1. Mr. Dunlop offers a complete outline of knowledge relevant to the management and direction of an organisation departmentally and as a whole. There is also a personal side devoted to individual diffioulties and requirements. The course is useful, not only to those who manage or who expect to, but also to professional and technical experts from the point of view of co-operative efficiency, and has been taken, either orally or by correspondence, by experienced account- ants, managers, industrial chemists and engineers in some of the largest industrial concerns. Critically selected references for reading are included. The course, which is personal and private, has its advisory professional practitioners from whom expert information and advice can be obtained when required, thereby combining the chief advantage of institutional instruction with private tuition.

\section{Medieval Spices}

Commentrng on a suggestion in a recent review of a leochbook in NATURE $(134,270$, Aug. 25, 1934) that certain spices "must have been hard to come by in fifteenth century England", Mr. G. M. Meyer, of 38 Manor Park Gardens, Edgware, points out that ginger and pepper must have been usual articles of commerce in the years $1300-1$, and presumably in later years, since they were then the subject of specified King's dues and of authorised brokerage charges at the port of Sandwich. The mere fact that a commodity is imported into a country does not necessarily imply that it is not difficult to obtain, at any rate by those not blessed with wealth and influence. The interesting historical account of pepper given by Fluckiger and Hanbury ("Pharmacographia"; London, Macmillan and Co., 1879) shows that it was only after the Portuguese, incited in part thereto by the high price of pepper, had discovered a sea-passage to India in 1498, that the cost of this condiment began to fall, and the following quotations from these authors seem to indicate that pepper was usually too uncertain in supply and too expensive to be regularly obtainable, except by the wealthy. "The price of pepper during the middle ages was always exorbitantly high, for the rulers of Egypt extorted a large revenue from all those who were engaged in the trade in it and other spices. The general prevalence during the middle ages of pepperrents, which consisted in an obligation imposed upon a tenant to supply his lord with a certain quantity of pepper, generally a pound, at stated times, shows how acceptable was this favourite condiment and how great the desire of the wealthier classes to secure a supply of it when the market was not always certain." Ginger was apparently not so commonly a subject of comment and controversy in medieval times as pepper, but it is on record that during the thirteenth and fourteenth centuries a pound of ginger cost about the price of a sheep.

\section{British Association Mathematical Tables}

The issue of Nature of March 17 gave a historieal account of the British Association's work since 1888 in the calculation of Bessel functions and of the financial difficulties which have impeded publication. It was pointed out that unless funds were provided, there was a danger that all this labour would result merely in a manuscript locked up in a fireproof safe. We are glad to hear that the appeal for funds has been successful; the British Association has contributed $£ 100$ and the Royal Society $£ 50$, and the publication of the tables is now assured. They will form vols. 6 and 7 of the Association's collection. The first three volumes have already been noticed 